\title{
Fallopian Tube Cancer pNO TNM Finding v7
}

National Cancer Institute

\section{Source}

National Cancer Institute. Fallopian Tube Cancer pNO TNM Finding v7. NCI Thesaurus. Code C89684.

Fallopian tube cancer without regional lymph node metastasis. (from AJCC 7th Ed.) 